\title{
Burial Diagenesis of Magnetic Minerals: New Insights from the Grès d'Annot Transect (SE France)
}

\author{
Myriam Kars ${ }^{1, \dagger, *}$, Charles Aubourg ${ }^{1}$, Pierre Labaume ${ }^{2}$, Thelma S. Berquó ${ }^{3}$ and \\ Thibault Cavailhes ${ }^{2,:}$
}

1 Laboratoire des Fluides Complexes et leurs Réservoirs, Université de Pau et des Pays de l'Adour, UMR 5150 CNRS TOTAL, Avenue de l’Université, 64013 Pau cedex, France;

E-Mail: charles.aubourg@univ-pau.fr

2 Géosciences Montpellier, Université de Montpellier 2, UMR 5243 CNRS, Place E. Bataillon, 34095 Montpellier cedex 5, France; E-Mails: pierre.labaume@gm.univ-montp2.fr (P.L.); thibault.cavailhes@dno.no (T.C.)

3 Physics Department, Concordia College, 901 8th St. S., Moorhead, MN 56562, USA; E-Mail: tberquo@cord.edu

† Current address: Center for Advanced Marine Core Research, Kochi University, B200 Monobe, 783-8502 Nankoku, Japan.

\$ Current address: DNO International ASA, P.O. Box 1345 Vika, 0113 Oslo, Norway.

* Author to whom correspondence should be addressed; E-Mail: jm-mkars@kochi-u.ac.jp; Tel.: +81-88-864-6728; Fax: +81-88-864-6713.

Received: 24 February 2014; in revised form: 14 May 2014 / Accepted: 17 June 2014 / Published: 10 July 2014

\begin{abstract}
The diagenetic evolution of the magnetic minerals during burial in sedimentary basins has been recently proposed. In this study, we provide new data from the Grès d'Annot basin, SE France. We analyze fine-grained clastic rocks that suffered a burial temperature from $\sim 60$ to $>250{ }^{\circ} \mathrm{C}$, i.e., covering oil and gas windows. Low temperature magnetic measurements $(10-300 \mathrm{~K})$, coupled with vitrinite reflectance data, aim at defining the magnetic mineral evolution through the burial history. Magnetite is documented throughout the entire studied transect. Goethite, probably occurring as nanoparticles, is found for a burial temperature $<80{ }^{\circ} \mathrm{C}$. Micron-sized pyrrhotite is highlighted for a burial temperature $>200{ }^{\circ} \mathrm{C}$ below the Alpine nappes and the Penninic Front. A model of the evolution of the magnetic assemblage from 60 to $>250{ }^{\circ} \mathrm{C}$ is proposed for clastic rocks, containing iron sulfides (pyrite)
\end{abstract}


and organic matter. This work provides the grounds for a better understanding of the magnetic properties of petroleum plays.

Keywords: Grès d'Annot basin; burial diagenesis; magnetite; pyrrhotite; paleotemperature

\section{Introduction}

Deciphering the way in which chemical and mineralogical processes operate in sedimentary basins is a major issue in order to understand their thermal history. These tools have especially great importance in applied geosciences, such as coal and petroleum geology, because they allow a better understanding of the source rock and reservoirs maturities.

In this perspective, the broad contours of the diagenesis of the magnetic minerals in argillaceous rocks were proposed from early burial (subsurface) to the lower greenschist facies metamorphism [1-7]. Recently, Aubourg et al. [8] defined three magnetic windows where greigite $\left(\mathrm{Fe}_{3} \mathrm{~S}_{4}\right.$; from subsurface to $\sim 8 \mathrm{~km}$ of depth, i.e., up to $\sim 200{ }^{\circ} \mathrm{C}$ ), magnetite $\left(\mathrm{Fe}_{3} \mathrm{O}_{4} ; \sim 2\right.$ to $\sim 12 \mathrm{~km}$ of depth, i.e., $\sim 50$ to $\sim 300{ }^{\circ} \mathrm{C}$ ) and pyrrhotite $\left(\mathrm{Fe}_{7} \mathrm{~S}_{8} ;>8 \mathrm{~km}\right.$ of depth, i.e., $\left.>200{ }^{\circ} \mathrm{C}\right)$ formed successively from low to deep burial by considering a geothermal gradient of $25{ }^{\circ} \mathrm{C} / \mathrm{km}$, which is typical in a foreland context. Thus, the magnetic assemblage of argillaceous rocks can be used to assess burial conditions and, particularly, burial temperatures (e.g., [9-12]). For high temperatures, the formation of pyrrhotite at the expense of magnetite and pyrite is reported by several studies when approaching $200{ }^{\circ} \mathrm{C}[3,4,13,14]$. More precisely, two isogrades based on the breakdown of magnetite $\left(\sim 250{ }^{\circ} \mathrm{C}\right)$ and the breakdown of pyrite $\left(>320^{\circ} \mathrm{C}\right.$ ) into monoclinic pyrrhotite were determined by Rochette [1] (see the review by [14]). For a burial temperature $>300^{\circ} \mathrm{C}$, neoformed pyrrhotite completely replaces magnetite according to:

$$
\mathrm{Fe}_{3} \mathrm{O}_{4}+3 \mathrm{FeS}_{2} \rightarrow 6 “ \mathrm{FeS} "+2 \mathrm{O}_{2}
$$

where "FeS" is pyrrhotite [15].

The formation of pyrrhotite $\left(\mathrm{Fe}_{1-x} \mathrm{~S}\right.$ with $\left.0<x<0.13\right)$ is hence of importance, as it may inform on low-grade metamorphic conditions $\left(>200^{\circ} \mathrm{C}\right)$ (e.g., [1-4]).

Nevertheless, the evolution of the magnetic minerals may not be straightforward. The greigite-magnetite-pyrrhotite pattern can be disrupted by the presence of inherited magnetic minerals (e.g., [16,17]), possibly occurring as nanoparticles (e.g., [18]), and by other neoformed magnetic minerals (e.g., maghemite, goethite). The relative amount of detrital magnetic minerals with respect to the neoformed minerals is debated. This proportion is probably dependent on several factors, including the nature and concentration of eroded magnetic particles, redox conditions during deposition, the chemistry of sediments, fluid circulation or bacterial activity (e.g., [19,20]).

In any case, the concentration of the magnetic minerals is generally low $(<1 \%)$. The magnetic minerals of interest in this study are sensu lato ferromagnetic, which have the capability to retain a remanent magnetization at room temperature when their size is single domain (SD) to multidomain (MD), i.e., above the blocking volume ( $\mathrm{Vb}$ ). The magnetic nanoparticles are difficult to detect, because they are in the superparamagnetic (SP) domain state with volume $<\mathrm{Vb}(<25 \mathrm{~nm}$ for magnetite) [21]. They do not carry a remanence at room temperature. In practical terms, the best way to detect SP 
grains is to use low temperature magnetic techniques (down to $10 \mathrm{~K}$ ), where the thermal energy is considerably reduced.

The present study aims to use the magnetic assemblage in clastic rocks as an estimate of the burial conditions, particularly for assessing maximum burial temperature. In this paper, we investigate the magnetic mineral assemblage in the clay-rich rocks from the Grès d'Annot basin, southeastern French Alps. Low-temperature magnetic measurements, compared to vitrinite reflectance data, aim at defining the magnetic windows. We study a $\sim 60 \mathrm{~km}$-long transect, where rocks from the same lithostratigraphic formations suffered from moderate diagenesis $\left(\sim 60{ }^{\circ} \mathrm{C}\right)$ in the external structural domain to anchimetamorphism $\left(\sim 250^{\circ} \mathrm{C}\right)$ in the internal domain.

\section{Geological Background}

\subsection{Geological Setting}

The Grès d'Annot foreland basin (SE France; Figure 1) formed in the late Eocene-early Oligocene times during the Alpine-Pyrenean orogeny [22-24]. It is characterized by a stratigraphic sequence, the so-called Trilogie Priabonnienne, that recorded the basin history [25]. The lower formations (infra-Nummulitic conglomerates, Calcaires Nummulitiques and Marnes Bleues), overlying the Mesozoic substratum, registered the initiation and deepening of the basin [26]. The Marnes Brunes Inférieures, Grès d'Annot Formation and Marnes Brunes Supérieures characterize the basin-filling phase [27]. The Grès d'Annot Formation corresponds to a Priabonian-Rupelian arkosic turbidite succession mainly sourced from the Variscan crystalline basement of the Corsica-Sardinia massif [28,29]. In the north-eastern part of the basin, these lithostratigraphic units were buried below the Embrunais-Ubaye alpine nappes, preceded by the Schistes à Blocs olistostrome, from the late Rupelian (Figure 1) [30,31]. The basin-fill constituted therefore the footwall of the nappes, the uppermost Grès d'Annot being close to the nappe sole thrust. The Grès d'Annot were then exhumed as a result of the uplift of the external basement massifs (Argentera, Pelvoux, Barrot Dôme) during the late Oligocene-early Miocene [30,32,33].

\subsection{Burial History}

The studied cross-section extends from Annot in the SW to Bersezio in the NE, parallel to the direction of thrusting of the Embrunais-Ubaye nappes and following their lateral erosion fringe (Figure 1). Organic matter-based, petrologic and thermochronologic studies permitted determining the burial and exhumation history of the Grès d'Annot basin along this transect [33-37].

Vitrinite reflectance (Ro) data available in the study area display an increasing trend from $0.3 \%$ in the Rouaine area (SW) up to $>7 \%$ underneath the Penninic Front at Gias Vallonetto (NE) (Figure 1) [34-36,38,39]. In the southwestern part, Ro values gradually increase from $0.3 \%$ in Rouaine to $0.6 \%-0.7 \%$ in the Grand Coyer area. NE of Grand Coyer, the Ro values first show an abrupt increase up to $2.0 \%-2.5 \%$ in the Estrop and Colmars areas, then a more progressive trend in the northeastern area, with values of $\sim 4 \%$ in La Moutière to more than $6 \%$ at Gias Vallonetto. According to the Vassoyevitch et al. [40] calibration, these Ro values correspond to temperatures increasing from $\sim 45{ }^{\circ} \mathrm{C}$ at Rouaine to $75{ }^{\circ} \mathrm{C}$ in the Grand Coyer area, to $\sim 160-180{ }^{\circ} \mathrm{C}$ in the Estrop and Colmars areas, to $\sim 230-240{ }^{\circ} \mathrm{C}$ at La Moutière and $\sim 250-270{ }^{\circ} \mathrm{C}$ at Gias Vallonetto [34-36]. 
Figure 1. Sampling sites and thermal data available for the study area (modified from Labaume et al. [33]). Dots represent the location of the samples analyzed in this study, with dark dots marking samples for which vitrinite reflectance data had been previously obtained on the same samples and white dot where vitrinite reflectance data were obtained from different samples in the same area. Vitrinite reflectance data and corresponding estimated temperatures are from Labaume et al. [34,35] and Cavailhes [36]. Isotherms were placed according to vitrinite data (ibid.), apatite fission tracks analyses and silica diagenesis [33,36]. 1: Embrunais-Ubaye nappes; 2: Middle Eocene to Priabonian (including the Grès d'Annot formation); 3: Mesozoic; 4: Paleozoic substratum; 5: base of allochthonous thrust units; 6: normal and strike-slip faults. A: Annot; Al: Allons; B: Braux; Co1-Co2: Colmars; GC: Grand Coyer; GV: Gias Vallonetto; MT: La Moutière; R: Rouaine; RU: Le Ruch; P: Peyresq; VC: Villars-Colmars.

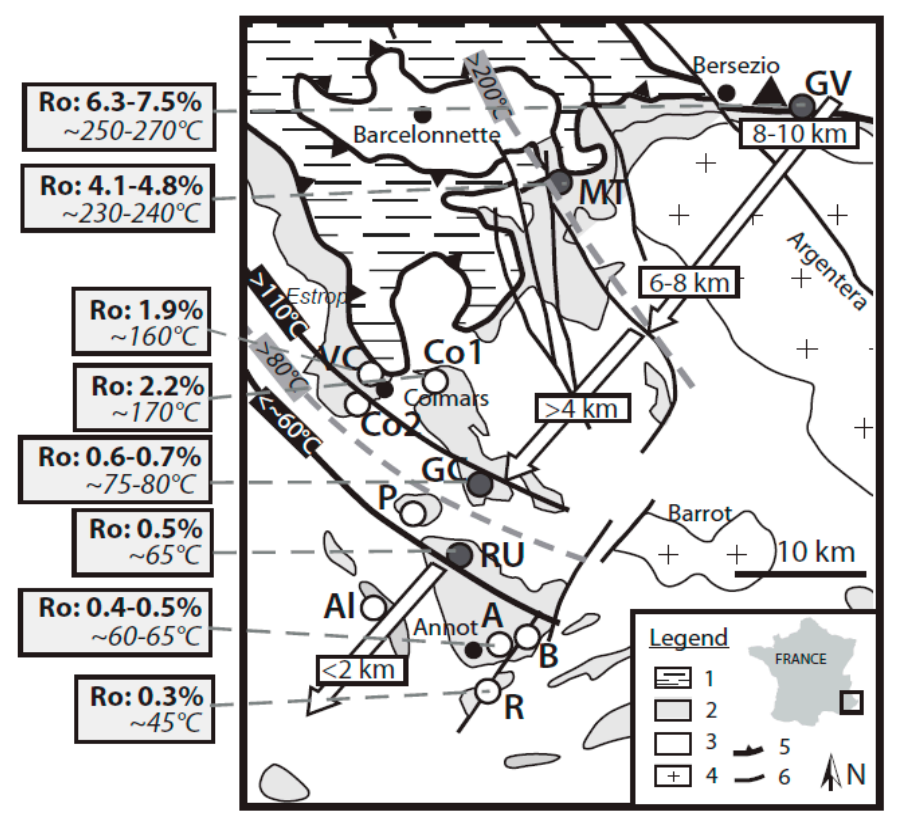

This evolution of the Ro values is consistent with the paleotemperature trends derived by Labaume et al. [33,34] from apatite fission tracks analysis (AFTA). These authors identified the upper boundary of the fission tracks partial annealing zone NE of Annot and the lower boundary NE of Grand Coyer, corresponding to the $\sim 60{ }^{\circ} \mathrm{C}$ and $\sim 110{ }^{\circ} \mathrm{C}$ isotherms, respectively (Figure 1). The trend of increasing paleotemperatures from SW to NE was also confirmed by petrological studies: the onset of silica diagenesis (marked by pressure solution of quartz), corresponding to $\sim 80{ }^{\circ} \mathrm{C}$, is located in the Grand Coyer area [34,37] and the abundant presence of authigenic sericite (white mica) in the La Moutière and Bersezio areas indicate temperatures $>200^{\circ} \mathrm{C}$ (Figure 1) [34,41,42]. In the fine-grained, clay-rich facies, the petrologic evolution is associated with a fissility that increases in intensity from the SW to the NE. This fissility is parallel to bedding in the pelitic layers of the Grès d'Annot turbidites and may correspond to an oblique cleavage in the Marnes Bleues (Figure 2).

The increase of temperature and fissility from the SW to the NE was interpreted to reflect the increasing burial, from $\sim 2 \mathrm{~km}$ in the $\mathrm{SW}$ area to up to $8-9 \mathrm{~km}$ in the NE, with the abrupt increase of temperature between Grand Coyer and the Estrop-Colmars area corresponding to the front of the Embrunais-Ubaye nappes [33-36]. 
Figure 2. Outcrop views of the Marnes Bleues at Le Ruch (a), Grand Coyer (b) and Gias Vallonetto (c), located in Figure 1 as RU, GC and GV, respectively. Note the increasing fissility from rough scaly fabric in (a) to pencil cleavage in (b) to crenulation cleavage in (c), related to increasing compaction and burial temperature from (a) to (c) (Figure 1).

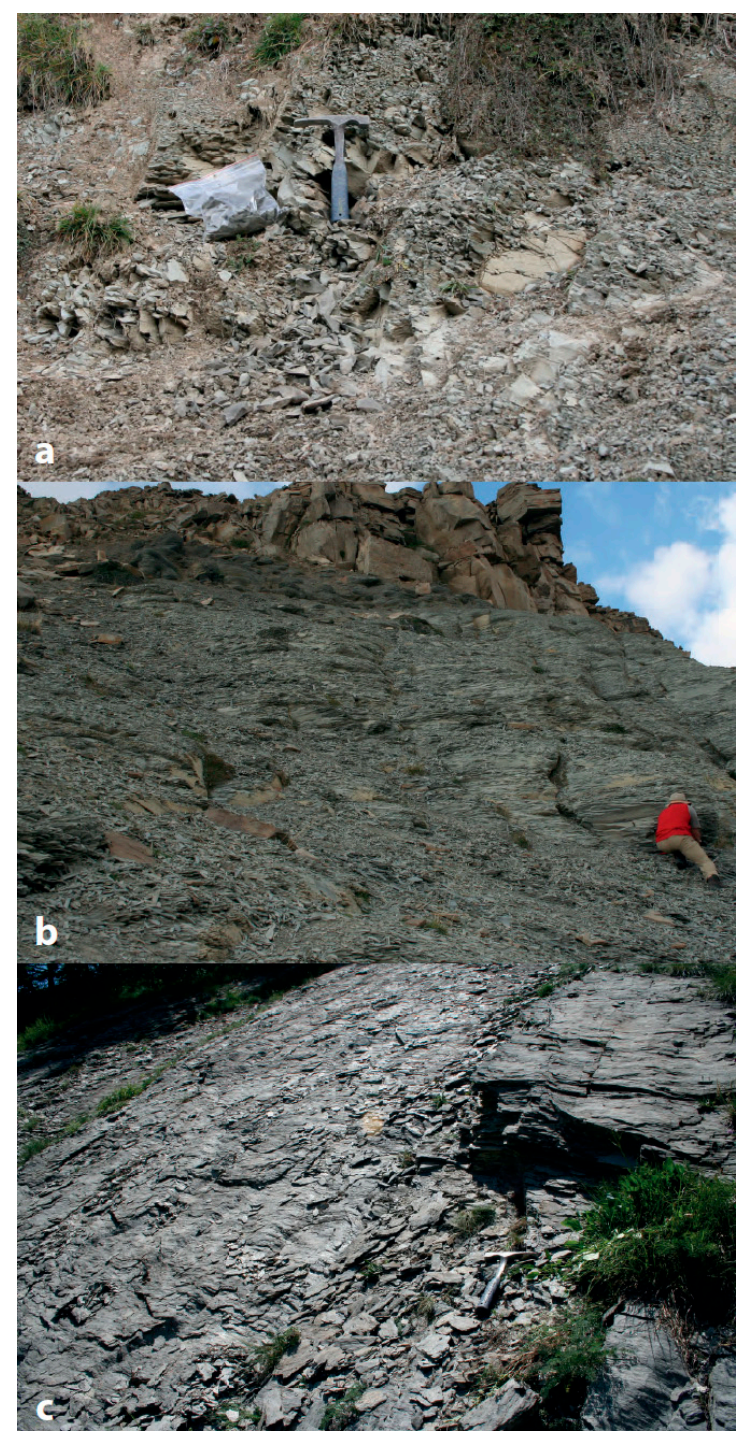

\section{Methods}

\subsection{Sampling and Mineralogy}

In this study, 36 samples from 12 different sites along the SW-NE transect, from the Rouaine area (SW) to Gias Vallonetto (NE), were analyzed (Table 1; Figure 1). They cover the entire temperature (depth) range of the Grès d'Annot basin burial history. The samples are very fine-grained argillaceous rocks corresponding to two different lithologies in the Nummulitic Trilogy: marls from the Marnes Bleues and turbiditic pelites from the Grès d'Annot and Marnes Brunes. The marls are rich in calcite $(30 \%-50 \%)$ with a subordinate amount of quartz, whereas the turbiditic pelites are rich in quartz, with minor calcite $(\sim 10 \%)$. Labaume et al. [34,35] have shown that the clay fraction $(<2 \mu \mathrm{m})$, similar in both marls and pelites from the Annot and Le Ruch areas, which suffered the weakest burial temperatures $\left(<70{ }^{\circ} \mathrm{C}\right.$ ), comprise $40 \%-60 \%$ illite (+illite-smectite), 10\%-20\% kaolinite, 10\%-20\% 
chlorite and, in some samples, up to $30 \%$ smectite. From Grand Coyer to NE of the study area, (1) kaolinite and smectite disappear and (2) illitisation increases, from neoformation of fiber-like illite particles at Grand Coyer $\left(T \sim 75^{\circ} \mathrm{C}\right)$ to small white mica particles at La Moutière $\left(T \sim 230-240{ }^{\circ} \mathrm{C}\right)$.

Table 1. Location of the sampling sites (ND: no data). The lithology and name of the formation in brackets are reported. MB1: Marnes Bleues; MBr: Marnes Brunes; GA: Grès d'Annot. Vitrinite reflectance data (Ro) and total organic carbon (TOC) content are also mentioned. SD: Standard deviation.

\begin{tabular}{|c|c|c|c|c|c|c|c|}
\hline Sampling Site & Sample & Latitude & Longitude & Lithology & Mean Ro (\%) & SD Ro & TOC (\%) \\
\hline \multirow{2}{*}{ Allons (Al) } & $1 \mathrm{~A}$ & $\mathrm{~N} 43^{\circ} 59^{\prime} 05.9^{\prime \prime}$ & E $6^{\circ} 34^{\prime} 56.3^{\prime \prime}$ & Marl (MBl) & & & \\
\hline & $2 \mathrm{~A}$ & $\mathrm{~N} 44^{\circ} 00^{\prime} 09.4^{\prime \prime}$ & E $6^{\circ} 34^{\prime} 11.1^{\prime \prime}$ & Marl (MBl) & & & \\
\hline \multirow{2}{*}{ Rouaine (R) } & $4 \mathrm{~A}$ & $\mathrm{~N} 43^{\circ} 56^{\prime} 01.1^{\prime \prime}$ & E $6^{\circ} 40^{\prime} 12.9^{\prime \prime}$ & Marl (MBl) & & & \\
\hline & $5 \mathrm{~A}$ & $\mathrm{~N} 43^{\circ} 56^{\prime} 06.6^{\prime \prime}$ & E $6^{\circ} 40^{\prime} 29.4^{\prime \prime}$ & Fine-grained sandstone (GA) & & & \\
\hline \multirow{2}{*}{ Braux (B) } & $6 \mathrm{~A}$ & $\mathrm{~N} 43^{\circ} 58^{\prime} 16^{\prime \prime}$ & E $6^{\circ} 42^{\prime} 17.2^{\prime \prime}$ & Marl (MBl) & & & \\
\hline & $7 \mathrm{~A}$ & $\mathrm{~N} 43^{\circ} 58^{\prime} 16^{\prime \prime}$ & E $6^{\circ} 42^{\prime} 17.2^{\prime \prime}$ & Fine-grained sandstone (GA) & & & \\
\hline \multirow{3}{*}{ Annot (A) } & A0 & $\mathrm{N} 43^{\circ} 57^{\prime} 43.1^{\prime \prime}$ & E $6^{\circ} 40^{\prime} 34.6^{\prime \prime}$ & Marl (MBl) & & & \\
\hline & $11 \mathrm{~A}$ & ND & ND & Marl (MBl) & & & \\
\hline & $12 \mathrm{~A}$ & ND & ND & Fine-grained sandstone (GA) & & & \\
\hline \multirow{2}{*}{ Le Ruch (RU) } & RUmg & $\mathrm{N} 44^{\circ} 02^{\prime} 40.5^{\prime \prime}$ & E $6^{\circ} 40^{\prime} 28.1^{\prime \prime}$ & Marl (MBl) & & & \\
\hline & RUmb & $\mathrm{N} 44^{\circ} 02^{\prime} 40.5^{\prime \prime}$ & E $6^{\circ} 40^{\prime} 28.1^{\prime \prime}$ & Turbiditic pelite (MBr) & 0.54 & 0.1 & 0.23 \\
\hline \multirow{8}{*}{ Grand Coyer (GC) } & CY1p & $\mathrm{N} 44^{\circ} 05^{\prime} 09.1^{\prime \prime}$ & E $6^{\circ} 41^{\prime} 0^{\prime \prime}$ & Turbiditic pelite (GA) & 0.61 & 0.07 & 0.35 \\
\hline & CY3p & $\mathrm{N} 44^{\circ} 05^{\prime} 09.1^{\prime \prime}$ & $\mathrm{E} 6^{\circ} 41^{\prime} 0^{\prime \prime}$ & Turbiditic pelite (GA) & 0.65 & 0.06 & 0.68 \\
\hline & CY5 & $\mathrm{N} 44^{\circ} 05^{\prime} 09.1^{\prime \prime}$ & E $6^{\circ} 41^{\prime} 0^{\prime \prime}$ & Turbiditic pelite (GA) & & & \\
\hline & CY6 & $\mathrm{N} 44^{\circ} 05^{\prime} 09.1^{\prime \prime}$ & E $6^{\circ} 41^{\prime} 0^{\prime \prime}$ & Turbiditic pelite (GA) & & & \\
\hline & $\mathrm{CY} 7$ & $\mathrm{~N} 44^{\circ} 05^{\prime} 09.1^{\prime \prime}$ & E $6^{\circ} 41^{\prime} 0^{\prime \prime}$ & Turbiditic pelite (GA) & & & \\
\hline & CY8 & $\mathrm{N} 44^{\circ} 05^{\prime} 09.1^{\prime \prime}$ & E $6^{\circ} 41^{\prime} 0^{\prime \prime}$ & Turbiditic pelite (GA) & & & \\
\hline & CY10 & $\mathrm{N} 44^{\circ} 05^{\prime} 09.1^{\prime \prime}$ & E $6^{\circ} 41^{\prime} 0^{\prime \prime}$ & Turbiditic pelite (GA) & & & \\
\hline & CY11 & 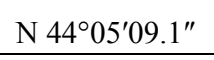 & E $6^{\circ} 41^{\prime} 0^{\prime \prime}$ & Turbiditic pelite (GA) & & & \\
\hline Peyresq (P) & $20 \mathrm{~A}$ & $\mathrm{~N} 44^{\circ} 02^{\prime} 12.0^{\prime \prime}$ & E $6^{\circ} 36^{\prime} 25.6^{\prime \prime}$ & Marl (MBl) & & & \\
\hline \multirow{3}{*}{ Colmars (Co1) } & $21 \mathrm{~A}$ & $\mathrm{~N} 44^{\circ} 09^{\prime} 11.1^{\prime \prime}$ & E $6^{\circ} 32^{\prime} 41.2^{\prime \prime}$ & Marl (MBl) & & & \\
\hline & $22 \mathrm{~A}$ & $\mathrm{~N} 44^{\circ} 09^{\prime} 26.2^{\prime \prime}$ & E $6^{\circ} 32^{\prime} 29.1^{\prime \prime}$ & Marl (MBl) & & & \\
\hline & $23 \mathrm{~A}$ & $\mathrm{~N} 44^{\circ} 09^{\prime} 49.3^{\prime \prime}$ & E $6^{\circ} 31^{\prime} 50.7^{\prime \prime}$ & Marl (MBl) & & & \\
\hline \multirow{2}{*}{ Colmars (Co2) } & $25 \mathrm{~A}$ & $\mathrm{~N} 44^{\circ} 09^{\prime} 07.7^{\prime \prime}$ & E $6^{\circ} 40^{\prime} 28.7^{\prime \prime}$ & $\operatorname{Marl}(\mathrm{MBl})$ & & & \\
\hline & $26 \mathrm{~A}$ & $\mathrm{~N} 44^{\circ} 09^{\prime} 26.9^{\prime \prime}$ & E $6^{\circ} 39^{\prime} 19.0^{\prime \prime}$ & Marl (MBl) & & & \\
\hline \multirow{3}{*}{ Villars-Colmars (VC) } & $13 \mathrm{~A}$ & ND & ND & Turbiditic pelite (GA) & & & \\
\hline & $14 \mathrm{~A}$ & ND & ND & Turbiditic pelite (GA) & & & \\
\hline & $15 \mathrm{~A}$ & ND & ND & Fine-grained sandstone (GA) & & & \\
\hline \multirow{5}{*}{ La Moutière (MT) } & MT12 & $\mathrm{N} 44^{\circ} 18^{\prime} 58^{\prime \prime}$ & E $6^{\circ} 47^{\prime} 46^{\prime \prime}$ & Turbiditic pelite (GA) & 4.06 & 0.16 & 0.34 \\
\hline & MT17 & $\mathrm{N} 44^{\circ} 18^{\prime} 58^{\prime \prime}$ & E $6^{\circ} 47^{\prime} 46^{\prime \prime}$ & Turbiditic pelite (GA) & & & \\
\hline & MT29 & $\mathrm{N} 44^{\circ} 18^{\prime} 58^{\prime \prime}$ & E $6^{\circ} 47^{\prime} 46^{\prime \prime}$ & Turbiditic pelite (GA) & 4.13 & 0.17 & 0.28 \\
\hline & MT120 & $\mathrm{N} 44^{\circ} 18^{\prime} 58^{\prime \prime}$ & E $6^{\circ} 47^{\prime} 46^{\prime \prime}$ & Turbiditic pelite (GA) & & & \\
\hline & MTmg & $\mathrm{N} \mathrm{44^{ \circ } 1 8 ^ { \prime } 5 8 ^ { \prime \prime }}$ & E $6^{\circ} 47^{\prime} 46^{\prime \prime}$ & Marl (MBl) & & & \\
\hline \multirow{3}{*}{ Gias Vallonetto (GV) } & GV1 & $\mathrm{N} 44^{\circ} 21^{\prime} 41.7^{\prime \prime}$ & E $7^{\circ} 03^{\prime} 32.4^{\prime \prime}$ & Turbiditic pelite (GA) & 6.29 & 0.41 & 0.61 \\
\hline & GV11 & $\mathrm{N} 44^{\circ} 21^{\prime} 41.7^{\prime \prime}$ & E $7^{\circ} 03^{\prime} 32.4^{\prime \prime}$ & Turbiditic pelite (GA) & 7.47 & 0.4 & 0.43 \\
\hline & GVmg & 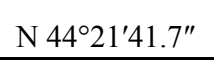 & E $7^{\circ} 03^{\prime} 32.4^{\prime \prime}$ & Marl (MBl) & & & \\
\hline
\end{tabular}




\subsection{Analytical Methods}

A series of different magnetic measurements were performed. The low-field magnetic susceptibility $(\chi)$ of these specimens was measured at the Ecole Normale Supérieure (ENS), Paris, France, with a KLY3-CS3 Kappabridge instrument. Then, the samples were crushed, and rock powders of 350-450 mg were sealed in gelatin capsules in order to perform low temperature magnetic measurement $(<300 \mathrm{~K})$. The evolution of a saturation isothermal remanent magnetization (SIRM) imparted at room temperature (RT-SIRM) with a $2.5 \mathrm{~T}$ magnetic field was monitored. Selected samples were heated to $400 \mathrm{~K}$. This heating phase aims at removing the goethite contribution (if any) by heating the sample through the Néel temperature $T_{\mathrm{N}}$ of goethite $\left(T_{\mathrm{N}}\right.$ goethite $\left.\sim 393 \mathrm{~K}\right)$ [43]. RT-SIRM $300 \mathrm{~K}$ refers to the value of the remanence at $300 \mathrm{~K}$ (before the heating phase in the case where the sample is heated). Then, the samples were cooled down to $10 \mathrm{~K}$ in the presence of a 5- $\mu \mathrm{T}$ magnetic field inside the magnetometer in order to highlight $<50 \mathrm{~K}$ magnetic behaviors [9,44]. The $5 \mu \mathrm{T}$ magnetic field was either oriented downward or upward. The magnetization measured in the 10-300 K temperature range was a combination of both remanent and induced (due to the 5- $\mu \mathrm{T}$ field) magnetizations. A back curve (warming to $300 \mathrm{~K}$ ) was measured for some samples. At $10 \mathrm{~K}$, a 2.5-T magnetic field was applied to create a low temperature SIRM (LT-SIRM), and the sample was warmed up to $300 \mathrm{~K}$ in zero field. This remanence evolution is called hereafter zero field cooled (ZFC). Some samples were cooled down to $10 \mathrm{~K}$ in a $2.5-\mathrm{T}$ field, before being warmed to $300 \mathrm{~K}$ in zero field. This remanence evolution is called FC (field cooled).

The low temperature magnetic measurements $(10-300 \mathrm{~K})$ were performed with two MPMS (Magnetic Properties Measurement System) cryogenic magnetometers. In addition, first-order reversal curves (FORC) and hysteresis loops were run at room temperature with a saturating field of $1 \mathrm{~T}$ by using a VSM (vibrating sample magnetometer). FORC diagrams were processed with FORCInel software [45]. Mössbauer spectra were measured at $300 \mathrm{~K}$ and $4.2 \mathrm{~K}$ for one selected sample in the Braux area. A conventional constant-acceleration spectrometer was used in transmission geometry with a ${ }^{57} \mathrm{Co} / \mathrm{Rh}$ source, using an $\alpha$-Fe foil at room temperature to calibrate isomer shifts and the velocity scale. Magnetic measurements (MPMS, VSM) and Mössbauer spectra were performed at the Institute for Rock Magnetism (IRM), University of Minnesota, Minneapolis, MN, USA.

Finally, some scanning electronic microscope (SEM) observations on selected specimens were made with a Zeiss SEM equipped with an X-ray energy dispersive spectrometer (EDS) at the ENS, Paris, France.

\section{Results}

\subsection{General Trends}

All of the samples have low-field magnetic susceptibility $(\chi<500 \mu \mathrm{SI})$ and an RT-SIRM $300 \mathrm{~K}$ comprised between 17 and $220 \mu \mathrm{Am}^{2} / \mathrm{kg}$ (Table 2). By plotting the data along the studied transect (Figure 3), no particular trend appears. Moreover, the evolution of these magnetic properties is not in agreement among each other, i.e., a $\chi$ increase may not be associated with an RT-SIRM $300 \mathrm{~K}$ increase. 
Table 2. Magnetic data and low temperature magnetic features for the collected samples. $\chi$ : low field magnetic susceptibility; RT-SIRM $300 \mathrm{k}$ : room temperature saturation isothermal remanent magnetization at $300 \mathrm{~K}$; LT-SIRM $10 \mathrm{~K}$ : low temperature saturation isothermal remanent magnetization at $10 \mathrm{~K}$.

\begin{tabular}{|c|c|c|c|c|}
\hline Sampling Site & Sample & $\chi(\boldsymbol{\mu S I})$ & $\begin{array}{c}\text { RT-SIRM }{ }_{300} \mathrm{~K} \\
\left(\mu \mathrm{Am} \mathbf{m}^{2} / \mathbf{k g}\right)\end{array}$ & $\begin{array}{c}\text { LT-SIRM }_{10 \mathrm{~K}} \\
\left(\mu \mathrm{Am} \mathbf{m}^{2} / \mathbf{k g}\right)\end{array}$ \\
\hline \multirow{2}{*}{ Allons (Al) } & $1 \mathrm{~A}$ & 74 & 18 & 387 \\
\hline & $2 \mathrm{~A}$ & 29 & 29 & 317 \\
\hline \multirow{2}{*}{ Rouaine (R) } & $4 \mathrm{~A}$ & 54 & 18 & 314 \\
\hline & $5 \mathrm{~A}$ & 28 & 29 & 148 \\
\hline \multirow{2}{*}{ Braux (B) } & $6 \mathrm{~A}$ & 171 & 42 & 572 \\
\hline & $7 \mathrm{~A}$ & 123 & 41 & 399 \\
\hline \multirow{3}{*}{ Annot (A) } & $\mathrm{A} 0$ & 101 & 28 & 378 \\
\hline & $11 \mathrm{~A}$ & 261 & 111 & 702 \\
\hline & $12 \mathrm{~A}$ & 170 & 92 & 905 \\
\hline \multirow{2}{*}{ Le Ruch (RU) } & RUmg & 152 & 116 & 642 \\
\hline & RUmb & 185 & 59 & 2,894 \\
\hline \multirow{8}{*}{ Grand Coyer (GC) } & CY1p & 201 & 32 & 1,372 \\
\hline & CY3p & 220 & 37 & 5,077 \\
\hline & CY5 & 229 & 37 & 1,334 \\
\hline & CY6 & 251 & 22 & 1,534 \\
\hline & CY7 & 231 & 35 & 1,976 \\
\hline & CY8 & 229 & 51 & 4,613 \\
\hline & CY10 & 168 & 24 & 329 \\
\hline & CY11 & 133 & 45 & 353 \\
\hline Peyresq (P) & $20 \mathrm{~A}$ & 45 & 29 & 422 \\
\hline \multirow{3}{*}{ Colmars (Co1) } & $21 \mathrm{~A}$ & 50 & 20 & 238 \\
\hline & $22 \mathrm{~A}$ & 60 & 25 & 205 \\
\hline & $23 \mathrm{~A}$ & 41 & 28 & 311 \\
\hline \multirow{2}{*}{ Colmars (Co2) } & $25 \mathrm{~A}$ & 121 & 78 & 1,212 \\
\hline & $26 \mathrm{~A}$ & 125 & 108 & 901 \\
\hline \multirow{3}{*}{ Villars-Colmars (VC) } & $13 \mathrm{~A}$ & 194 & 27 & 783 \\
\hline & $14 \mathrm{~A}$ & 128 & 72 & 981 \\
\hline & $15 \mathrm{~A}$ & 205 & 220 & 816 \\
\hline \multirow{5}{*}{ La Moutière (MT) } & MT12 & 307 & 35 & 2,249 \\
\hline & MT17 & 259 & 59 & 7,148 \\
\hline & MT29 & 301 & 34 & 3,208 \\
\hline & MT120 & 198 & 39 & 3,359 \\
\hline & MTmg & 130 & 17 & 467 \\
\hline \multirow{3}{*}{ Gias Vallonetto (GV) } & GV1 & 239 & 23 & 10,265 \\
\hline & GV11 & 244 & 39 & 709 \\
\hline & GVmg & 26 & 113 & 538 \\
\hline \multirow{5}{*}{ La Moutière (MT) } & MT12 & 307 & 35 & 2,249 \\
\hline & MT17 & 259 & 59 & 7,148 \\
\hline & MT29 & 301 & 34 & 3,208 \\
\hline & MT120 & 198 & 39 & 3,359 \\
\hline & MTmg & 130 & 17 & 467 \\
\hline \multirow{3}{*}{ Gias Vallonetto (GV) } & GV1 & 239 & 23 & 10,265 \\
\hline & GV11 & 244 & 39 & 709 \\
\hline & GVmg & 26 & 113 & 538 \\
\hline
\end{tabular}


Figure 3. Magnetic susceptibility and saturation isothermal remanent magnetization at room temperature $($ RT-SIRM $300 \mathrm{~K})$ values along the Grès d'Annot transect. No particular trend appears.

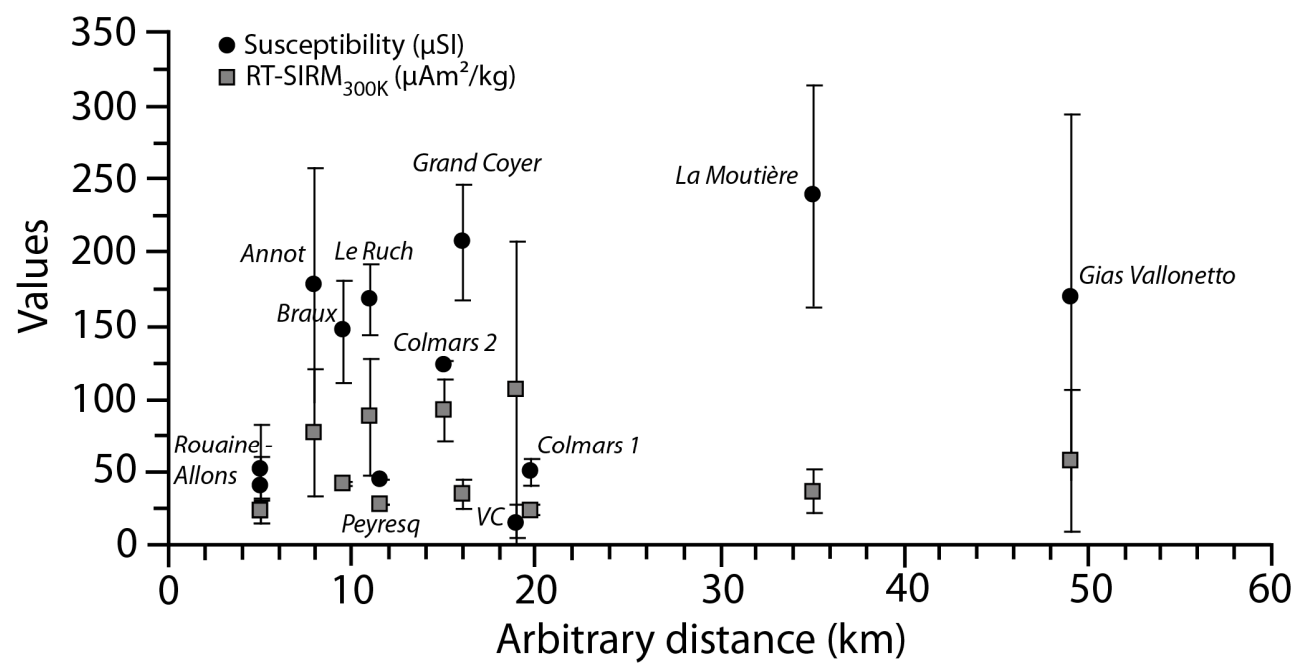

Room temperature measurements (FORC diagrams and hysteresis loops) bring general information on the mineral coercivity and grain size. In the SW part of the study area (Allons-Rouaine-Annot), the FORC diagrams show a coercivity field $H \mathrm{c}<20 \mathrm{mT}$, suggesting that a low coercivity magnetic mineral, occurring in a single domain size, is present (Figure 4a). This is supported by the hysteresis loops that saturate at $1 \mathrm{~T}$ (Figure 4c). This mineral is probably magnetite (e.g., [21]). In the Le Ruch-Grand Coyer area, FORCs diagrams and hysteresis loops are not interpretable, because of a very low concentration of ferromagnetic particles. At Gias Vallonetto area, for sample GVmg, the hysteresis loop is wasp-waisted, which indicates either a magnetic assemblage of at least two minerals with different coercivities or different sizes of the same mineral (Figure 4f) [46]. One is probably magnetite, because saturation is reached before $1 \mathrm{~T}$. The other one presents a higher coercivity, probably pyrrhotite (identified on the low temperature measurements). The FORC diagram shows the occurrence of a low coercivity single domain mineral, probably magnetite (Figure 4d).

Additional mineralogical information is provided by the low temperature magnetic measurements that show typical magnetic features. These measurements allow the recognition of the magnetic minerals based on their characteristic magnetic behavior below room temperature. The most common observation in the studied samples is the drop of the remanence acquired at room temperature (RT-SIRM) at $110-120 \mathrm{~K}$, which corresponds to the Verwey transition of magnetite $[47,48]$. This feature is observed throughout the entire studied transect from SW to NE. Some samples display an increase of the RT-SIRM when cooling down to $10 \mathrm{~K}$. This increase is generally $>30 \%$, suggesting the occurrence of goethite [49]. Nevertheless, if the increase is lower $(\sim 10 \%)$, then it could be due to maghemite [50]. At a very low temperature $(<50 \mathrm{~K})$, two magnetic behaviors can be observed. The most common observation is a sudden increase (decrease) of the RT-SIRM below $50 \mathrm{~K}$. This is actually a combination of both remanent and induced magnetizations as a result of the upward (downward) application of the 5 - $\mu \mathrm{T}$ magnetic field inside the MPMS. This behavior is called P-behavior and characterizes the paramagnetic minerals (e.g., submicron pyrrhotite, Fe-Mn carbonates) [9,44]. The second magnetic behavior is the Besnus transition of pyrrhotite, which displays a decrease of the remanence at 
$\sim 32-35 \mathrm{~K}$ [51-53]. This particular magnetic behavior is only observed in the NE part of the study area (Villars-Colmars, La Moutière, Gias Vallonetto). Finally, the remanence acquired at a low temperature (LT-SIRM) shows also a typical evolution. On the LT-SIRM curve, a fall of the remanence can be observed from 10 to $35 \mathrm{~K}$. A parameter, called PM, was defined by Aubourg and Pozzi [9] to characterize this drop and aims at assessing the SP/SD ratio [54]. Other LT-SIRM curves display an inflection point at $\sim 200-250 \mathrm{~K}$, suggesting the occurrence of very small particles or minerals with a high Curie/Néel temperature (e.g., high-Ti titanomagnetite, hematite). Nevertheless, the occurrence of a high Curie/Néel temperature is unlikely, because the remanence is removed by $\sim 600{ }^{\circ} \mathrm{C}$ when performing thermal demagnetization (not shown).

Figure 4. First-order reversal curves (FORC) diagrams (a,d) and hysteresis loops, both uncorrected (b,e) and corrected (c,f), run at room temperature for two samples. SF is the smoothing factor. Note that the corrected hysteresis loops are noisy (weak signal), as a result of the low concentration of ferromagnetic particles.

\section{Allons area, SW (Sample 2A)}
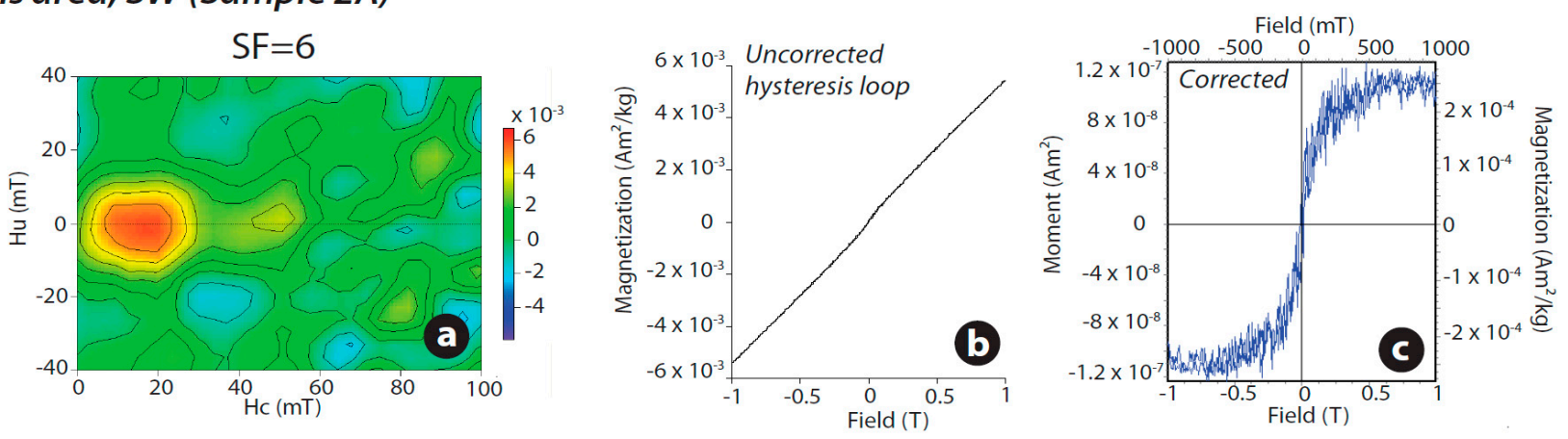

\section{Gias Vallonetto area, NE (Sample GVmg)}
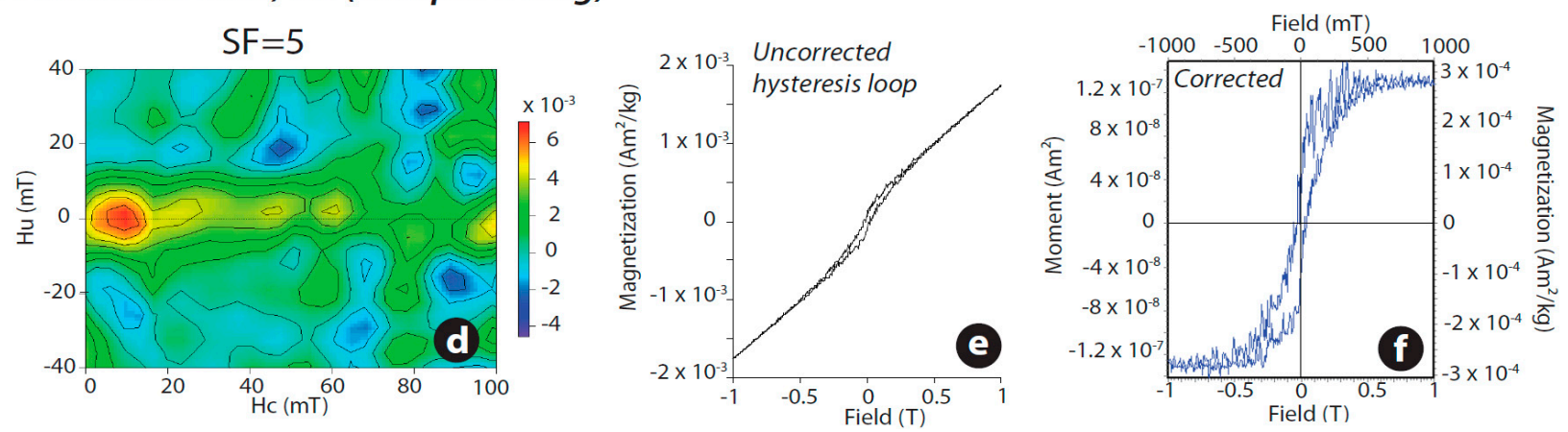

\subsection{Allons, Rouaine and Annot Areas}

The magnetic signal observed in those areas (Al, R and A in Figure 1, respectively) displays generally an LT-SIRM curve with a two-step pattern $[9,44]$. This pattern is represented by an important decrease of the LT-SIRM from 10 to $35 \mathrm{~K}$ and a Verwey transition of magnetite at $\sim 120 \mathrm{~K}$. For Sample 12A in the Annot area, 56\% of the LT-SIRM is lost from 10 to $35 \mathrm{~K}(\mathrm{PM}=0.56)$ (Figure 5a). The Verwey transition is easily recognizable in the RT-SIRM curve, and the P-behavior is observed (Figure $5 \mathrm{~b}$ ). When warming back to $300 \mathrm{~K}$, the curve is not reversible from $\sim 70-80 \mathrm{~K}$, i.e., from a temperature lower than that of the Verwey transition. This is certainly due to a maghemitization effect caused by the preliminary heating at $400 \mathrm{~K}$ [50]. 
Figure 5. Evolution of the saturation isothermal remanent magnetization for four characteristic samples from the Grès d'Annot basin with increasing burial. LT-SIRM (a,c,e,g) and RT-SIRM (b,d,f,h) curves are shown. Note that the slight discontinuity on the LT-SIRM (both zero field cooled (ZFC) and FC) curves at $\sim 50 \mathrm{~K}$ is due to a change in the measurement sequence. $\mathrm{Mg}$, magnetite; P-b, P-behavior; Po, pyrrhotite; $\mathrm{nG}$, nanogoethite.
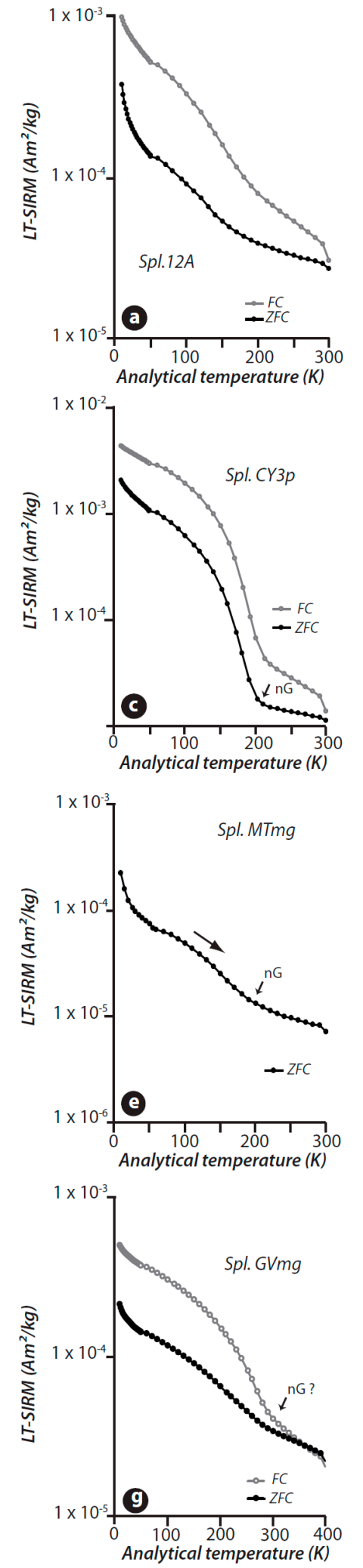
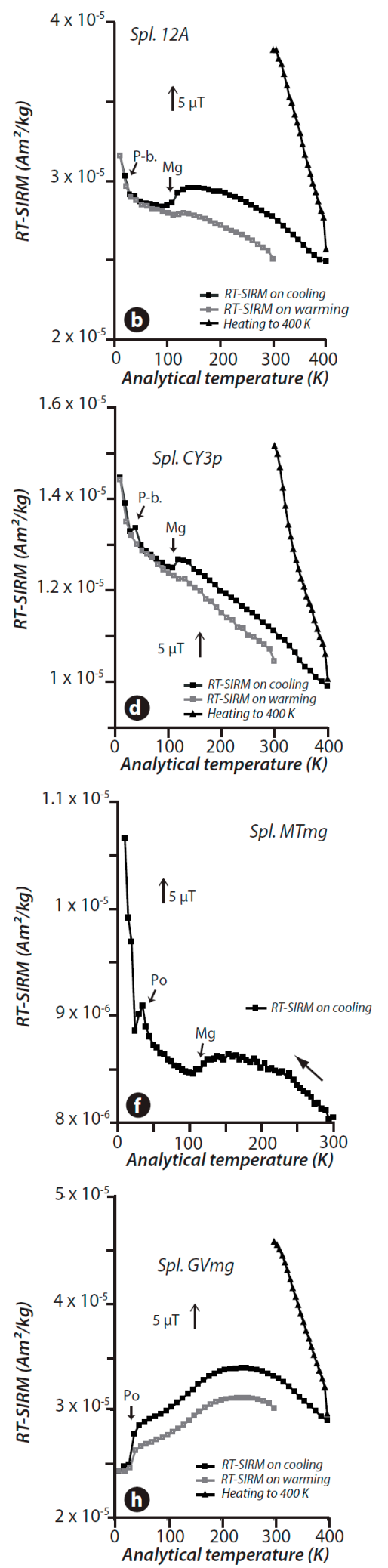

$<65^{\circ} \mathrm{C}$

Ro $~ 0.4-0.5 \%$

$>75^{\circ} \mathrm{C}$

Ro $\sim 0.6-0.7 \%$

Increasing burial

temperature

$>220^{\circ} \mathrm{C}$

Ro $>4 \%$

$>250^{\circ} \mathrm{C}$

Ro $>6 \%$ 


\subsection{Braux Area}

The LT-SIRM evolution of Sample 6A in the Braux area (B in Figure 1) appears to decrease regularly when warming to room temperature and does not display a distinct two-step pattern as identified in the Allons, Rouaine and Annot areas (Figure 6a). The RT-SIRM curve shows the Verwey transition of magnetite and an increase by $42 \%$ of the remanence from 300 to $\sim 35 \mathrm{~K}$ (Figure 6a), characteristic of goethite [49]. In order to check the occurrence of goethite, Mössbauer spectra were performed at 300 and $4.2 \mathrm{~K}$ on the bulk sample. At room temperature, the Mössbauer spectrum is fitted with three doublets corresponding to contributions of $\mathrm{Fe}^{2+}$ and $\mathrm{Fe}^{3+}$ (not shown). These components may be associated with paramagnetic iron silicates and, in addition, the $\mathrm{Fe}^{3+}$ doublet of smaller QS (quadrupole splitting) may also be related to the presence of superparamagnetic iron oxide. In order to observe the presence of superparamagnetic thermal relaxation, the spectrum was taken at low temperature. At $4.2 \mathrm{~K}$, a small sextet contribution $(\sim 8 \%)$ is observed and its hyperfine parameters reflect the presence of goethite (Figure $6 \mathrm{~b}$ ). The $B_{\mathrm{HF}}$ (magnetic hyperfine field) has a small decrease as compared with a stoichiometric goethite of $B_{\mathrm{HF}}$ of $50.6 \mathrm{~T}$, and it could be associated with the presence of lattice defects (vacancies or isomorphic substitution) [55].

Figure 6. Sample (Spl.) 6A (Braux area). (a) RT-SIRM and ZFC curves in the 10-300 K range and (b) Mössbauer spectrum at $4.2 \mathrm{~K}$. Note that the RT-SIRM increase from 300 to $35 \mathrm{~K}$ by $42 \%$ showing that the presence of goethite is confirmed by the occurrence of the goethite (G) sextet on the Mössbauer spectrum.
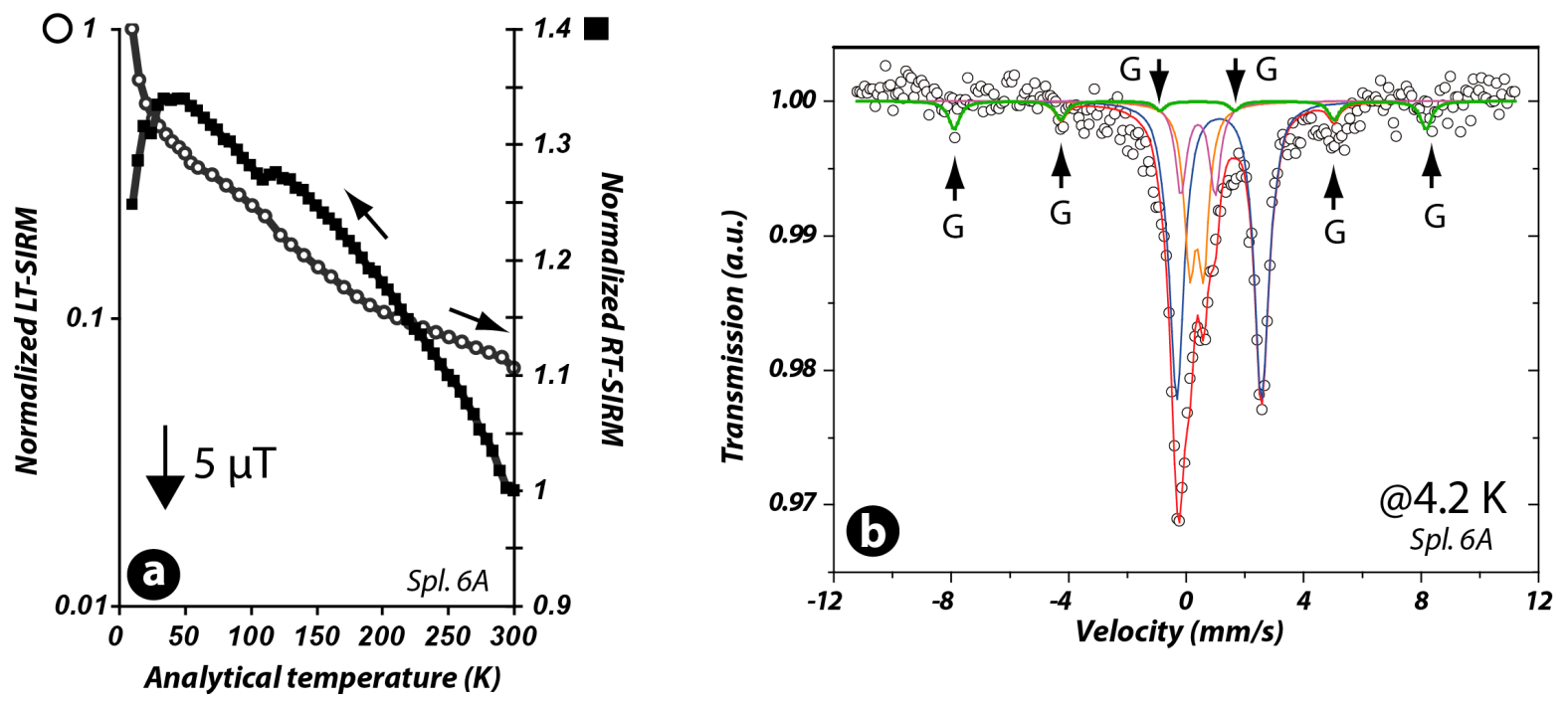

\subsection{Le Ruch and Grand Coyer Areas}

The RT-SIRM curves of the samples from the Le Ruch and Grand Coyer (RU and GC in Figure 1, respectively) areas show a remanence increase from 300 to $10 \mathrm{~K}$, with a drop at $\sim 120 \mathrm{~K}$ (Verwey transition) and a change-in-slope at $\sim 35 \mathrm{~K}$ (P-behavior). For the sample, CY3p (Grand Coyer area), $47 \%$ of remanence increases from 300 to $10 \mathrm{~K}$ (Figure $5 \mathrm{~d}$ ), that is typical of goethite. The particular feature of that area is that the LT SIRM curves (both ZFC and FC) display an inflection point at about 200-250 K (Figure 5c), suggesting the presence of nanoparticles, likely goethite (e.g., [56]). 


\subsection{Villars-Colmars, La Moutière and Gias Vallonetto Areas}

The LT-SIRM curves for samples from the Villars-Colmars and La Moutière areas (VC and MT in Figure 1, respectively) show an inflection point at $\sim 150 \mathrm{~K}$, whereas it occurs at $\sim 200-250 \mathrm{~K}$ for Gias Vallonetto (GV in Figure 1) (Figures 5e and 5g). The RT-SIRM increase from 300 to $10 \mathrm{~K}$ is between $6 \%$ and $15 \%$ for the MT samples. These percentage values might be attributed to maghemite or goethite [50]. Goethite, however, usually shows a higher percentage increase ( $>30 \%)$, as is the case for the GV specimens. Differentiating between these two minerals in the MT area needs more data. The important magnetic observation for three samples from the VC, MT and GV areas is the Besnus transition of pyrrhotite. Sample MTmg from La Moutière (Figure 5f) displays a transition similar to the sample, 14A, from the VC area (not shown). Sample GVmg displays, however, a remanent magnetic evolution characteristic of micron-sized $(>1 \mu \mathrm{m})$ pyrrhotite (Figure $5 \mathrm{~h})[1,51,52]$.

\section{Discussion}

Performing and combining different magnetic techniques appear to be useful and necessary to determine the magnetic assemblage of the studied samples. Low and room temperature magnetic measurements have provided complementary information on the magnetic minerals constitutive of the studied rocks.

\subsection{Origin of the Magnetic Assemblage}

Nano magnetite (SD size) is ubiquitous, present throughout the entire Grès d'Annot transect, whereas goethite is identified from the Braux area to the Gias Vallonetto area. Micron pyrrhotite is identified below the Embrunais-Ubaye nappes (Villars-Colmars, La Moutière) and the Penninic Front (Gias Vallonetto).

If RT-SIRM $300 \mathrm{~K}\left(<5 \times 10^{-4} \mathrm{Am}^{2} / \mathrm{kg}\right)$ is assumed to be carried half by goethite and half by magnetite, it is possible to calculate the maximum concentration of goethite and magnetite in the samples. By considering $\mathrm{Mrs}_{\mathrm{mag}} \sim 10 \mathrm{Am}^{2} / \mathrm{kg}$ for soft magnetite $\left(\mathrm{c}_{\mathrm{mag}}=\mathrm{RT}-\mathrm{SIRM}_{300 \mathrm{~K}} / 2 \mathrm{Mrs}_{\mathrm{mag}}\right)$ and $\mathrm{Mrs}_{\text {goe }} \sim 0.05 \mathrm{Am}^{2} / \mathrm{kg}$ for goethite $\left(\mathrm{c}_{\text {goe }}=\mathrm{RT}-\mathrm{SIRM}_{300 \mathrm{~K}} / 2 \mathrm{Mrs}_{\text {goe }}\right.$ ) [57], the calculation suggests that $<0.5 \%$ of goethite and a trace amount of magnetite $(<25 \mathrm{ppmv})$ are present. If magnetite is the main magnetic carrier of the remanence, then $<50$ ppmv of ferromagnetic particles are present.

From Le Ruch to Gias Vallonetto, the inflection point at $200-250 \mathrm{~K}$ observed in the LT-SIRM curves (both ZFC and FC; Figure 5) might be an indicator of nanoparticles of goethite [58]. The origin of nanogoethite is debated. It might represent an alteration product developed as a result of fluid circulation (e.g., [59]). As the tectonic contact of the nappes is not so far from the sampling sites, this possibility cannot be ruled out. A second explanation might be that nanogoethite was neoformed as a result of particular burial conditions. Indeed, based on vitrinite reflectance data, Cavailhes [36] showed that there was probably a stacking of the Embrunais-Ubaye and Parpaillon alpine nappes NE of the Grand Coyer area, leading to an abrupt increase of burial northeastwards. Nevertheless, recent weathering might also be responsible for the formation of goethite, as goethite is a common alteration by-product.

In the Villars-Colmars, La Moutière and Gias Vallonetto areas, micron pyrrhotite is identified. It has been proposed that pyrrhotite could form by the reaction of pyrite with magnetite and organic 
matter in metamorphic conditions [1], even at a low temperature $\left(<200{ }^{\circ} \mathrm{C}\right)$ [15]. Framboidal grains, mainly composed of pyrite, were examined, because they are often associated with organic matter as a result of the bacterial activity [60]. In samples from the Villars-Colmars area, framboidal structures present a rim darker than the core (Figure 7a). An EDS transect from the core to the outer zone reveals that the $\mathrm{Fe} / \mathrm{S}$ ratio varies with a decrease in $\mathrm{S}$ content toward the rim (Figure $7 \mathrm{~b}$ ). The oxidation rim is certainly magnetite. Replacement of pyrite by magnetite has been widely described in previous studies (e.g., [61,62]). Some alteration features are also observed in euhedral grains, which most likely represent dissolution features. In samples from La Moutière and Gias Vallonetto, EDS analyses indicate that $\mathrm{Fe}$ and $\mathrm{O}$ are the main constituents in framboidal structures: the former pyrite framboids seem totally oxidized into magnetite. The presence of pyrrhotite could not be documented in our SEM observations, most likely because of its extremely low concentration.

Figure 7. (a) Scanning Electronic Microscope (SEM) observation of a pyrite framboid with an oxidation rim (Spl. 14A) and (b) its associated Energy Dispersive Spectrometer (EDS) profile. Note that the $\mathrm{Fe}$ and $\mathrm{S}$ contents evolve along the profile, with $\mathrm{S}$ being concentrated in the inner part of the framboid.
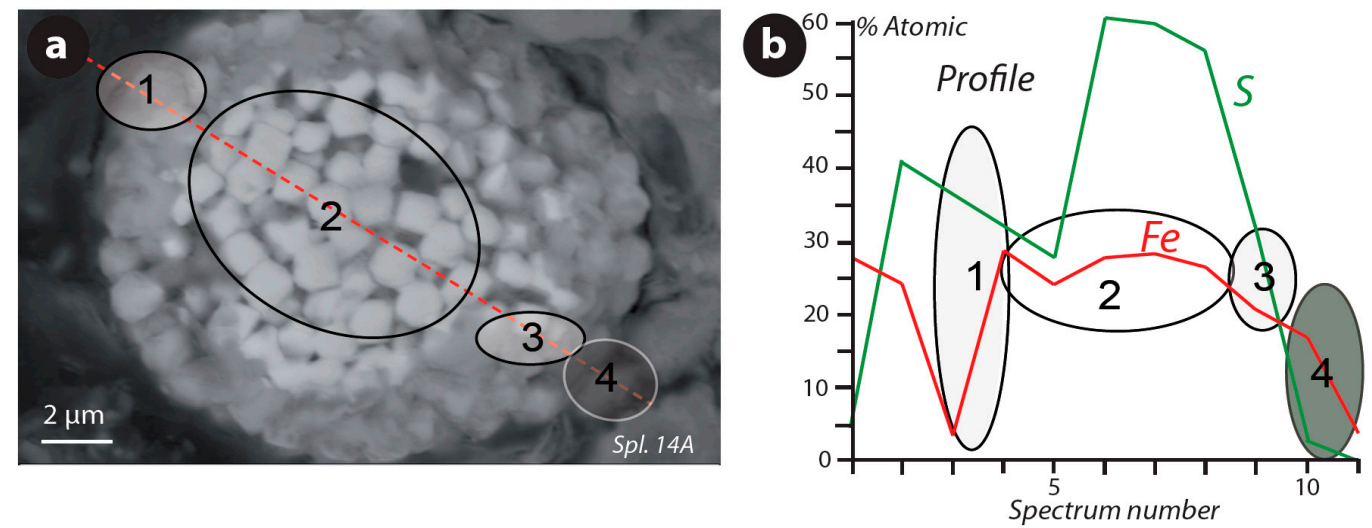

\subsection{Toward a Burial Model}

Based on laboratory heating experiments and the literature, Aubourg et al. [8] have proposed a burial model divided into three magnetic windows, as described in the Introduction. In the following, an attempt is done to refine their model based on natural observations from the Grès d'Annot transect (Figure 8). Though marls and pelites differ by their mineralogical composition, which may influence the formation of magnetic minerals, they are not distinguished in the burial model presented below. Indeed, the model is global, taking into account prior observations made from clay-rich rocks (with no distinction of the clay composition). If clay diagenesis has an influence on the magnetic mineralogy, likely on the iron supply, it is probably in terms of the temperature $\left( \pm 50^{\circ} \mathrm{C}\right)$ of the first occurrence of a given magnetic mineral.

In the study area, an evolution of the magnetic assemblage from SW to NE is observed, consistent with increasing vitrinite reflectance values and maximum burial temperatures.

In the SW (Rouaine, Allons, Annot, Braux), the maximum temperature experienced by the rocks was $\sim 60{ }^{\circ} \mathrm{C}$ (i.e., a burial depth $\sim 2-3 \mathrm{~km}$ assuming a $30{ }^{\circ} \mathrm{C} / \mathrm{km}$ geothermal gradient), with vitrinite reflectance Ro $<0.6 \%$. SD magnetite and iron sulfides are the main constituents. Neoformed magnetite 
is very common in sedimentary rocks. Many studies reported the presence of iron sulfides (pyrite, greigite) at a temperature $<50^{\circ} \mathrm{C}$ (e.g., [6,63]). Iron sulfides are produced during early diagenesis by the destruction of the detrital magnetic minerals by bacterial activity (e.g., [19]). In the southwestern part of the study area, pyrite, greigite and submicron pyrrhotite occur.

On the other hand, Abdelmalak et al. [10] stated that goethite (called goethite A in Figure 8) could be used as a marker of the immature rocks $($ Ro $<0.5 \%)$ for claystones in volcanic margins. Blaise et al. [11] also identified goethite for immature rocks in the Paris Basin. The samples from the Braux area show the occurrence of goethite, suggesting that this zone experienced temperatures below $60{ }^{\circ} \mathrm{C}$ if the burial diagenesis hypothesis is favored. Even though it could be concordant with the isotherms established by Labaume et al. [33], alteration might also be evoked to explain the occurrence of goethite.

Figure 8. Global burial model for magnetic minerals in clay-rich rocks. The burial temperatures are deduced from the vitrinite reflectance data by using the Vassoyevitch et al. [40] calibration [34-36]. See the text for a discussion. References: 1: this study; 2: [10]; 3: [9]; 4: [11]; 5: [12]; 6: [64].

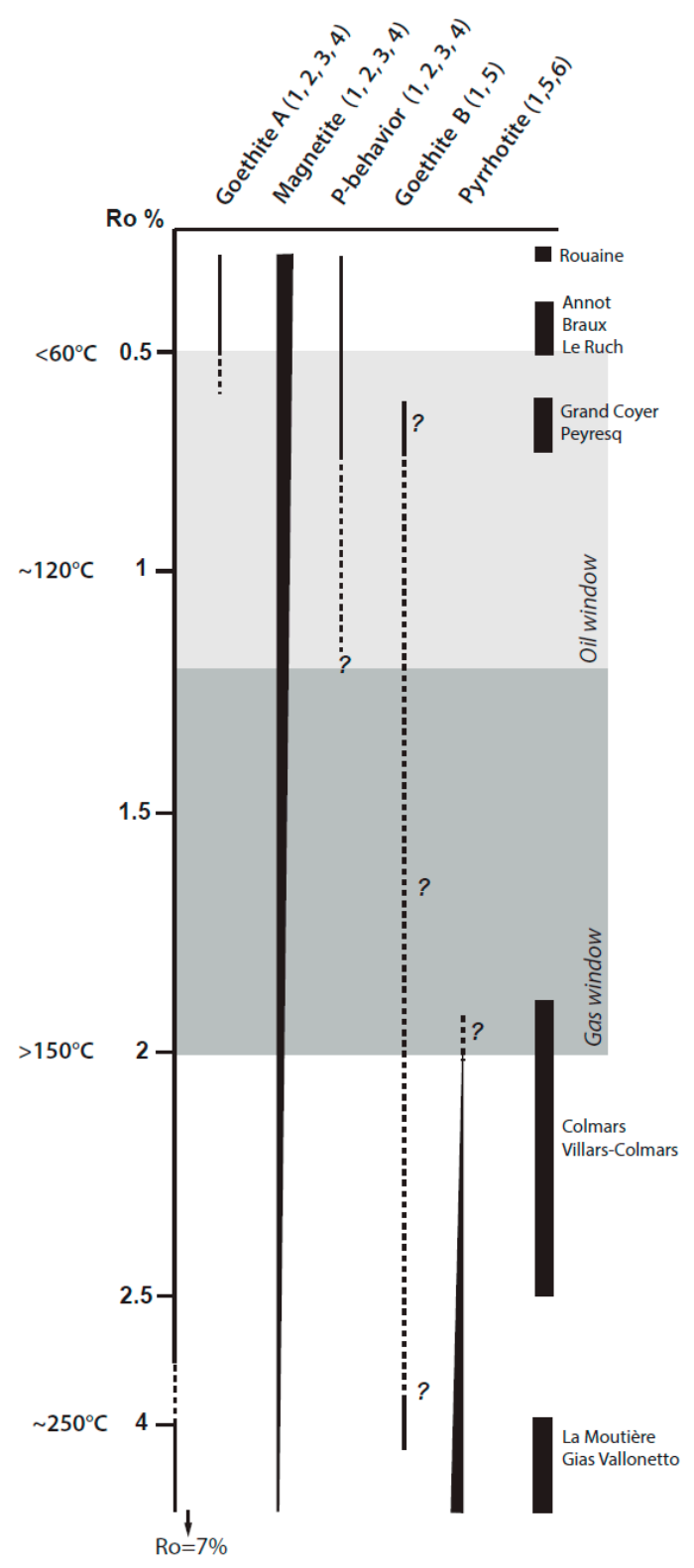


Based on heating experiments, magnetite is expected to be present in rocks experiencing a wide temperature range from $\sim 60{ }^{\circ} \mathrm{C}$ to $>200{ }^{\circ} \mathrm{C}$, including oil and gas windows [8,9,54,65-67]. In the study area, magnetite is found throughout the entire transect in rocks that experienced a burial temperature $<250{ }^{\circ} \mathrm{C}$. Many studies reported also the occurrence of SD magnetite for such temperatures (e.g., [9-12,64]).

From Le Ruch to La Moutière, the magnetic assemblage is mainly composed of magnetite and goethite nanoparticles. The goethite origin is discussed above. Further information is needed to favor one hypothesis among others.

In the NE area (Colmars, Villars-Colmars, La Moutière, Gias Vallonetto), which is characterized by a burial temperature $>200{ }^{\circ} \mathrm{C}$ (burial depth $\sim 8-10 \mathrm{~km}$ ), the magnetic assemblage is mainly constituted of magnetite and $>1 \mu \mathrm{m}$ pyrrhotite. Micron-sized pyrrhotite was also observed in Alpine limestone metamorphic units, northward to our study area, which experienced also such a temperature range (e.g., $[1,52,68])$. Micron pyrrhotite is a common finding in such metamorphic units. It is also observed in the Himalayas metamorphic limestones [4,14] and in clay-rich metamorphic rocks in Taiwan [17].

Rochette [1] was the first to map metamorphic isogrades using the ferromagnetic susceptibility in the Helvetic Jurassic black shales from the Alps. He proposed two metamorphic reactions; (1) the breakdown of magnetite in favor of pyrrhotite near $250{ }^{\circ} \mathrm{C}$, and (2) at a higher temperature $\left(\sim 320-350{ }^{\circ} \mathrm{C}\right)$, the breakdown of pyrite in favor of pyrrhotite in lower greenschist facies. The pyrite-pyrrhotite reaction leads to an increase of ferromagnetic susceptibility by two orders of magnitude. Similarly, in Taiwan, Horng et al. [17] used hysteresis loops on magnetic extracts to map anchizone $\left(<250^{\circ} \mathrm{C}\right)$ from epizone $\left(>250{ }^{\circ} \mathrm{C}\right)$ metamorphic grades. They observed a distinct magnetic assemblage. In anchizone, the hysteresis loops display straight lines, with subtle ferromagnetic contribution. By contrast, when entering the epizone, the hysteresis loops of the magnetic extract display a diagnostic "wide shape" that is characteristic of pyrrhotite. Similarly to Rochette [1] study, Horng et al. [17] observed a net gain of remanence by one order of magnitude for shales from the anchizone to the epizone. It can be assumed that pyrrhotite results from the pyrite breakdown according to the equilibrium proposed by Rochette [1]. Interestingly, along several sections in Taiwan, including the sampling of Horng et al. [17], Beyssac et al. [69] provided a comprehensive map of burial paleotemperatures derived from Raman spectroscopy. When comparing these burial temperatures and the map of the first occurrence of the "wide loop" of pyrrhotite [17], it is suggested that the pyrite-pyrrhotite reaction occurred for a temperature $>350 \pm 30{ }^{\circ} \mathrm{C}$.

In the study area, $>1 \mu \mathrm{m}$ of pyrrhotite is detected at Gias Vallonetto, and thus, it is questionable whether the pyrrhotite results from magnetite breakdown or pyrite breakdown. Two observations suggest that the pyrite breakdown temperature is not reached. First, with respect to other southern sites, there is no significant enhancement of remanence (Figure 3 and Figure 5h). Second, magnetite is detected from the FORC diagram (Figure 4d), and the wasp-wasted shape of hysteresis loops suggests that magnetite is therefore not entirely consumed (Figure 4f). Therefore, the burial temperature at Gias Vallonetto is suggested to be lower than $350^{\circ} \mathrm{C}$, i.e., lower than the pyrite breakdown temperature. This is consistent with the burial temperature derived from vitrinite reflectance data (Ro $<7.5 \%$ ) when using the Vassoyevitch et al. [40] calibration curve. It is worth reminding that this calibration curve was chosen because of its consistency with apatite fission track data [33]. The chemical kinetic model proposed by Sweeney and Burnham [70] cannot be used, because it is valid on a range of Ro between 
$0.3 \%$ and $4.5 \%$. Barker and Pawlewicz [71] proposed an empirical calibration curve just as Vassoyevitch et al. [40]. When using this calibration, a burial temperature about $30-40{ }^{\circ} \mathrm{C}$ higher than that given by the Vassoyevitch et al. [40] calibration is estimated, i.e., also coherent with a burial temperature $<350{ }^{\circ} \mathrm{C}$, suggested by the observation of the magnetic assemblage (magnetite and pyrrhotite).

By summarizing and generalizing the results from the Grès d'Annot transect with other studies, a global burial model for magnetic minerals in clay-rich rocks (in a broad sense) is proposed (Figure 8). One requirement for the formation of magnetic minerals is that the rocks need to contain iron sulfides (pyrite) and organic matter as starting materials. Goethite (goethite A) for immature rocks $\left(<50{ }^{\circ} \mathrm{C}\right)$ is mentioned, though its occurrence could be due to the weathering effect. Iron sulfides (and detrital iron oxides) are, however, the main magnetic minerals present in immature rocks. After early diagenesis, magnetite is the main iron oxide formed under increasing temperature (up to $\sim 250{ }^{\circ} \mathrm{C}$ ). Then, magnetite progressively disappears in favor of pyrrhotite. For a burial temperature $>200-250{ }^{\circ} \mathrm{C}$, micron-sized pyrrhotite is the main magnetic mineral present, though magnetite may still be present.

\subsection{Analog for a Gas Shale System?}

The magnetic mineralogy of the studied clay-rich rocks is similar to that encountered in gas shales, such as the Marcellus and Barnett Shales, USA [12,72]. First, the concentration of the ferromagnetic minerals is very low $(<50 \mathrm{ppmv})$. Second, the magnetic mineralogy seems to evolve in a similar way. Micron-sized pyrrhotite occur for a high burial temperature $\left(>150-200{ }^{\circ} \mathrm{C}\right)$. This finding has been reported by recent studies on the Marcellus Shales in the Appalachians [12,64]. Because they experienced a broad range of burial temperature from $<60{ }^{\circ} \mathrm{C}$ to $>250{ }^{\circ} \mathrm{C}$, which covers oil and gas windows, the clay-rich rocks from the Grès d'Annot basin could be considered as an analog of a gas shale system from the immature to overmature stage.

\section{Conclusions}

In the Grès d'Annot basin, the magnetic assemblage evolves throughout a wide temperature range $\left(50\right.$ to $>250{ }^{\circ} \mathrm{C}$ ) from SW to NE (Penninic Front). Magnetite progressively disappears in favor of pyrrhotite with increasing temperature. Nevertheless, magnetite is still present in the high temperature area (Gias Vallonetto). Pyrrhotite $(>1 \mu \mathrm{m})$ is highlighted for rocks that experienced a temperature $>200-250^{\circ} \mathrm{C}$ and, thus, could be a marker of the anchimetamorphism. Based on these observations, a burial diagenesis model of the magnetic minerals, including pyrrhotite, magnetite and goethite, is attempted.

For temperature $<60{ }^{\circ} \mathrm{C}$, iron sulfides, nanogoethite and magnetite are present. For higher temperatures covering oil and gas windows $\left(\sim 60-150{ }^{\circ} \mathrm{C}\right)$, magnetite is mainly identified, though the occurrence of other magnetic minerals cannot be ruled out. For a temperature $>150{ }^{\circ} \mathrm{C}$, magnetite and micron-sized pyrrhotite are the main magnetic minerals. For a temperature $>250{ }^{\circ} \mathrm{C}$, magnetite progressively disappears in favor of pyrrhotite, indicating low-grade metamorphism. The assemblage of magnetite and pyrrhotite indicates that the burial temperature is $<350{ }^{\circ} \mathrm{C}$ in the most buried site (Gias Vallonetto). 
Because of their mineralogy and burial history in a foreland context, the clay-rich rocks from the Grès d'Annot basin might be considered as an analog for a gas shale system.

The comprehension of the magnetic minerals diagenesis through the oil and gas windows of source rocks has probably profound consequences for the interpretation of magnetic anomalies above petroleum plays. The next stage of this work would be to study the paleomagnetic record, assuming a continuous production and destruction of magnetic minerals.

\section{Acknowledgments}

This work was conducted as a part of Myriam Kars's Ph.D. thesis supported by Total S.A./Université de Pau et des Pays de l'Adour, France. We are grateful to the Institute for Rock Magnetism, University of Minnesota, Minneapolis, MN, USA, for providing us instrumental facilities (MPMS and VSM) and for fruitful discussions. We benefited from a grant from the University of Minnesota for our 10-day visit at the IRM in 2010. We would like to thank Alexandra Abrajevitch and an anonymous reviewer for their constructive comments on the prior versions of this manuscript.

\section{Author Contributions}

Myriam Kars performed the magnetic measurements and handled the paper, including the text and figures. Charles Aubourg, the former advisor of Myriam Kars, provided the initial idea to collect samples along this transect. He contributed to the interpretation of rock magnetic data. Pierre Labaume, who already published a study along this transect, provided additional samples and data and greatly improved the paper by providing observations and comments. Thelma S. Berquó led the Mössbauer study presented in this paper. Thibault Cavailhes provided a part of the data set.

\section{Conflicts of Interest}

The authors declare no conflict of interest.

\section{References}

1. Rochette, P. Metamorphic control of the magnetic mineralogy of black shales in the Swiss Alps: Toward the use of "magnetic isogrades". Earth Planet. Sci. Lett. 1987, 84, 446-456.

2. Dunlop, D.; Özdemir, O.; Clark, D.; Schmidt, P. Time-temperature relations for the remagnetization of pyrrhotite $\left(\mathrm{Fe}_{7} \mathrm{~S}_{8}\right)$ and their use in estimating paleotemperatures. Earth Planet. Sci. Lett. 2000, 176, 107-116.

3. Crouzet, C.; Ménard, G.; Rochette, P. Cooling history of the Dauphinoise Zone (Western Alps, France) deduced from the thermopaleomagnetic record: Geodynamic implications. Tectonophysics 2001, 340, 79-93.

4. Schill, E.; Appel, E.; Gautam, P. Towards pyrrhotite/magnetite geothermometry in low-grade metamorphic carbonates of the Thethyan Himalayas (Shiar Khola, Central Nepal). J. Asian Earth Sci. 2002, 20, 195-201.

5. Roberts, A.P.; Weaver, R. Multiple mechanisms of remagnetization involving sedimentary greigite $\left(\mathrm{Fe}_{3} \mathrm{~S}_{4}\right)$. Earth Planet. Sci. Lett. 2005, 231, 263-277. 
6. Rowan, C.J.; Roberts, A.P.; Broadbent, T. Reductive diagenesis, magnetite dissolution, greigite growth and paleomagnetic smoothing in marine sediments: A new view. Earth Planet. Sci. Lett. 2009, 277, 223-235.

7. Roberts, A.P.; Chang, L.; Rowan, C.J.; Horng, C.S.; Florindo, F. Magnetic properties of sedimentary greigite $\left(\mathrm{Fe}_{3} \mathrm{~S}_{4}\right)$ : An update. Rev. Geophys. 2011, 49, doi:10.1029/2010RG000336.

8. Aubourg, C.; Pozzi, J.-P.; Kars, M. Burial, claystones remagnetization and some consequence for magnetostratigraphy. In Remagnetization and Chemical Alteration of Sedimentary Rocks; Elmore, R.D., Muxworthy, A.R., Aldana, M.M., Mena, M., Eds.; Special Publications Volume 371; Geological Society London: London, UK, 2012; pp. 181-188.

9. Aubourg, C.; Pozzi, J.-P. Toward a new $<250{ }^{\circ} \mathrm{C}$ pyrrhotite-magnetite geothermometer for claystones. Earth Planet. Sci. Lett. 2010, 294, 47-57.

10. Abdelmalak, M.; Aubourg, C.; Geoffroy, L.; Laggoun-Defarge, F. A new oil window indicator? The magnetic assemblage of claystones from the Baffin Bay volcanic margin (Greenland). AAPG Bull. 2012, 96, 205-215.

11. Blaise, T.; Barbarand, J.; Kars, M.; Ploquin, F.; Aubourg, C.; Brigaud, B.; Cathelineau, M.; El Albani, A.; Gautheron, C.; Izart, A.; et al. Reconstruction of low temperature $\left(<100{ }^{\circ} \mathrm{C}\right)$ burial in sedimentary basins: A comparison of geothermometer sensibility in the intracontinental Paris Basin. Mar. Pet. Geol. 2014, 53, 71-87.

12. Kars, M.; Aubourg, C.; Suárez-Ruiz, I. Neoformed magnetic minerals as an indicator of moderate burial: The key example of Middle Paleozoic sedimentary rocks, West Virginia, WV, USA. AAPG Bull. 2014, accepted for publication.

13. Rochette, P.; Lamarche, G. Evolution des propriétés magnétiques lors des transformations minérales dans les roches: Exemple du Jurassique Dauphinois (Alpes françaises). Bull. Mineral. 1986, 109, 687-696. (In French)

14. Appel, E.; Crouzet, C.; Schill, E. Pyrrhotite Remagnetizations in the Himalaya: A Review. In Remagnetization and Chemical Alteration of Sedimentary Rocks; Elmore, R.D., Muxworthy, A.R., Aldana, M.M., Mena, M., Eds.; Special Publications Volume 371; Geological Society London: London, UK, 2012; pp. 163-180.

15. Gillett, S.L. Paleomagnetism of the Notch Peak contact metamorphic aureole revisited: Pyrrhotite form magnetite+pyrite under sbmetamorphic conditions. J. Geophys. Res. 2003, 108, 2446, doi:10.1029/2002JB002386.

16. Horng, C.S.; Torii, M.; Shea, K.S.; Kao, S.J. Inconsistent magnetic polarities between greigite and pyrrhotite/magnetite-bearing marine sediments from the Tsailiao-chi section. Earth Planet. Sci. Lett. 1998, 164, 467-481.

17. Horng, C.S.; Huh, C.A.; Chen, K.H.; Lin, C.H.; Shea, K.S.; Hsiung, K.H. Pyrrhotite as a tracer for denudation of the Taiwan orogen. Geochem. Geophys. Geosyst. 2012, 13, doi:10.1029/2012GC004195.

18. Roberts, A.P.; Chang, L.; Heslop, D.; Florindo, F.; Larrasoaña, J.C. Searching for single domain magnetite in the "pseudo-single-domain" sedimentary haystack: Implications of biogenic magnetite preservation for sediment magnetism and relative paleointensity determinations. J. Geophys. Res. 2012, 117, doi:10.1029/2012JB009412. 
19. Canfield, D.E.; Berner, R.A. Dissolution and pyritization of magnetite in anoxic marine sediments. Geochim. Cosmochim. Acta 1987, 51, 645-659.

20. Bloemendal, J.; King, J.; Hunt, A.; DeMenocal, P.; Hayashida, A. Origin of the sedimentary magnetic record at Ocean Drilling Program sites on the Owen Ridge, western Arabian Sea. J. Geophys. Res. 1993, 98, 4199-4219.

21. Dunlop, D.; Özdemir, O. Rock Magnetism: Fundamentals and Frontiers; Cambridge University Press: Cambridge, UK, 1997.

22. Ford, M.; Lickorish, W.H.; Kusznir, N.J. Tertiary foreland sedimentation in the southern subalpine chains, SE France: A geodynamic appraisal. Basin Res. 1999, 11, 315-336.

23. Ford, M.; Lickorish, W.H. Foreland basin evolution around the western Alpine arc. In Deep-water Sedimentation in the Alpine Basin of SE France: New Perspectives on the Grès d'Annot and Related Systems; Joseph, P., Lomas, S.A., Eds.; Special Publications Volume 221; Geological Society London: London, UK, 2004; pp. 39-63.

24. Joseph, P.; Lomas, S. Deep-water sedimentation in the Alpine Foreland Basin of SE France: A new perspective on the Grès d'Annot and related systems: An introduction. In Deep-water Sedimentation in the Alpine Basin of SE France: New Perspectives on the Grès d'Annot and Related Systems; Joseph, P., Lomas, S.A., Eds.; Geological Society London, Special Publications: London, UK, 2004; Volume 221, pp. 1-16.

25. Ravenne, C.; Vially, R.; Riche, P.; Trémolières, P. Sédimentation et tectonique dans le bassin éocène sup-oligocène des Alpes du Sud. Rev. Inst. Fr. Pet. 1987, 42, 529-553. (In French)

26. Apps, G.; Peel, F.; Elliott, T. The structural setting and palaeogeographical evolution of the Grès d'Annot basin. In Deep-water Sedimentation in the Alpine Basin of SE France: New Perspectives on the Grès d'Annot and Related Systems; Joseph, P., Lomas, S.A., Eds.; Geological Society London, Special Publications: London, UK, 2004; Volume 221, pp. 65-96.

27. Du Fornel, E.; Joseph, P.; Desaubliaux, G.; Eschard, R.; Guillocheau, F.; Lerat, O.; Muller, C.; Ravenne, C.; Sztrakos, K. The southern Grès d'Annot out crops (French Alps): An attempt at regional correlation. In Deep-water Sedimentation in the Alpine Basin of SE France: New Perspectives on the Grès d'Annot and Related Systems; Joseph, P., Lomas, S.A., Eds.; Geological Society London, Special Publications: London, UK, 2004; Volume 221, pp. 137-160.

28. Jean, S.; Kerckhove, C.; Perriaux, J.; Ravenne, C. Un modèle Paléogène de bassin à turbidites: Les Grès d'Annot du NW du massif de l'Argentera-Mercantour. Geol. Alp. 1985, 61, 115-143. (In French)

29. Garcia, D.; Joseph, P.; Maréchal, B.; Moutte, J. Patterns of geochemical variability in relation to turbidite facies in the Grès d'Annot Formation. In Deep-water Sedimentation in the Alpine Basin of SE France: New Perspectives on the Grès d'Annot and Related Systems; Joseph, P., Lomas, S.A., Eds.; Geological Society London, Special Publications: London, UK, 2004; Volume 221, pp. 349-365.

30. Kerckhove, C. La “zone du flysch” dans les nappes de l'Embrunais-Ubaye (Alpes occidentales). Geol. Alp. 1969, 45, 1-202.

31. Sztrakos, K.; Du Fornel, E. Stratigraphie, paléoécologie et foraminifères du Paléogène des Alpes Maritimes et des Alpes de Haute-Provence (Sud-Est de la France). Rev. Micropaleontol. 2003, 46, 229-267. (In French) 
32. Labaume, P.; Ritz, J.-F.; Philip, H. Failles normales récentes dans les Alpes sud-occidentales: Leurs relations avec la tectonique compressive. Comptes Rendus Acad. Sci. 1989, 308, 1553-1560. (In French)

33. Labaume, P.; Jolivet, M.; Souquière, F.; Chauvet, A. Tectonic control on diagenesis in a foreland basin: Combined petrologic and thermochronologic approaches in the Grès d'Annot basin (late Eocene-Early Oligocene, French-Italian external Alps). Terra Nova 2008, 20, 95-101.

34. Labaume, P.; Arnaud, N.; Buatier, M.; Charpentier, D.; Chauvet, A.; Chirouze, F.; Jolivet, M.; Monié, P.; Sizun, J.-P.; Travé, A. Contrôle Tectonique de la Diagenèse d'une Formation Turbiditique d'Avant-Chaine, Exemple des Grés d'Annot, Alpes Externes Franco-Italiennes; Unpublished Internal Report; TOTAL: Pau, France, 2008. (In French)

35. Labaume, P.; Sizun, J.-P.; Charpentier, D.; Travé, A.; Chirouze, F.; Buatier, M.; Chauvet, A.; Walgenwitz, F.; Jolivet, M.; Monié, P.; et al. Diagenesis controlled by tectonic burial in a foreland basin turbidite formation. The case example of the Grès d'Annot, French-Italian external Alps. In Proceedings of the European Geosciences Union (EGU) General Assembly, Vienna, Austria, 19-24 April 2009.

36. Cavailhes, T. Architecture et Propriétés Pétrophysiques des Zones de Failles dans une Série Gréso Pélitique Turbiditique Profondément Enfouie: Rôle de la Déformation et des Interactions Fluide-Roche. Ph.D. Thesis, Université de Montpellier 2, Montpellier, France, 2012. (In French)

37. Souquière, F. Relations Tectonique/Diagenèse dans un Bassin d'Avant-Chaîne, Exemple des Grès d'Annot: Approche Pétrologique et Thermochronologiques. Master's Thesis, Université de Montpellier 2, Montpellier, France, 2005. (In French)

38. Barlier, J.; Ragot, J.-P.; Thouray, J.-C. L'évolution des Terres Noires subalpines méridionales d'après l'analyse minéralogique des argiles et la réflectance des particules carbonées. Bull. BRGM 1974, 6, 533-548.

39. Pickering, K.; Hilton, V. Turbidite Systems of Southern France: Application to Hydrocarbon Prospectivity; Vallis Press: London, UK, 1998.

40. Vassoyevitch, N.B.; Korchagina, N.V.; Lopatin, N.V.; Chernyshev, V.V. Principal phase of oil formation. Int. Geol. Rev. 1970, 12, 1276-1297.

41. Leclère, H.; Buatier, M.; Charpentier, D.; Sizun, J.-P.; Labaume, P.; Cavailhes, T. Formation of phyllosilicates in fault zone affecting deeply buried arkosic sandstones. Their influence on fault zone petrophysic properties (Annot sandstones, late Eocene-early Oligocene, external Alps). Swiss J. Geosci. 2012, 105, 299-312.

42. Cavailhes, T.; Sizun, J.-P.; Labaume, P.; Chauvet, A.; Buatier, M.; Soliva, R.; Gout, C. Influence of fault rock foliation on fault zone permeability: The case of deeply buried arkosic sandstones (Grès d'Annot, SE France). AAPG Bull. 2013, 97, 1521-1543.

43. Özdemir, O.; Dunlop, D. Thermoremanence and Néel temperature of goethite. Geophys. Res. Lett. 1996, 23, 921-924.

44. Kars, M.; Aubourg, C.; Pozzi, J.-P. Low temperature magnetic behaviour near $35 \mathrm{~K}$ in unmetamorphosed claystones. Geophys. J. Int. 2011, 186, 1029-1035.

45. Harrison, R.; Feinberg, J. FORCinel: An improved algorithm for calculating first-order reversal curve distributions using locally weighted regression smoothing. Geochem. Geophys. Geosyst. 2008, 9, doi:10.1029/2008GC001987. 
46. Tauxe, L.; Mullender, T.; Pick, T. Potbellies, wasp-waists, and superparamagnetism in magnetic hysteresis. J. Geophys. Res. 1996, 101, 571-583.

47. Muxworthy, A.R.; McClelland, E. Review of the low-temperature magnetic properties of magnetite from a rock magnetic perspective. Geophys. J. Int. 2000, 140, 101-114.

48. Özdemir, O.; Dunlop, D.; Moskowitz, B. Changes in remanence, coercivity and domain state at low-temperature in magnetite. Earth Planet. Sci. Lett. 2002, 194, 343-358.

49. Dekkers, M.J. Magnetic properties of natural goethite-II. TRM behaviour during thermal and alternating field demagnetization and low-temperature treatment. Geophys. J. Int. 1989, 97, 341-355.

50. Özdemir, O.; Dunlop, D. Hallmarks of maghemitization in low-temperature remanence cycling of partially oxidized magnetite nanoparticles. J. Geophys. Res. 2010, 115, doi:10.1029/2009JB006756.

51. Dekkers, M.J.; Mattéi, J.-L.; Fillion, G.; Rochette, P. Grain-size dependence of the magnetic behavior of pyrrhotite during its low-temperature transition at 34 K. Geophys. Res. Lett. 1989, 16, 855-858.

52. Rochette, P.; Fillion, G.; Mattéi, J.-L.; Dekkers, M.J. Magnetic transition at 30-34 Kelvin in pyrrhotite: Insight into a widespread occurrence of this mineral in rocks. Earth Planet. Sci. Lett. 1990, 98, 319-328.

53. Wolfers, P.; Fillion, G.; Ouladdiaf, B.; Ballou, R.; Rochette, P. The pyrrhotite $32 \mathrm{~K}$ magnetic transition. Solid State Phenom. 2011, 170, 174-179.

54. Kars, M.; Aubourg, C.; Pozzi, J.-P.; Janots, D. Continuous production of nanosized magnetite through low grade burial. Geochem. Geophys. Geosyst. 2012, 13, doi:10.1029/2012GC004104.

55. Murad, E.; Cashion, J. Mössbauer Spectroscopy of Environmental Materials and Their Industrial Utilization; Kluwer Academic Publishers: Boston, MA, USA, 2013.

56. Guyodo, Y.; Mostrom, A.; Penn, R.L.; Banerjee, S.K. From nanodots to nanorods: Oriented aggregation and magnetic evolution of nanocrystalline goethite. Geophys. Res. Lett. 2003, 30, doi:10.1029/2003GL017021.

57. Maher, B.A.; Thompson, R. Quaternary Climates, Environments and Magnetism; Cambridge University Press: Cambridge, UK, 1999.

58. Guyodo, Y.; LaPara, T.M.; Anschutz, A.J.; Penn, R.L.; Banerjee, S.K. Rock magnetic, chemical and bacterial community analysis of a modern soil from Nebraska. Earth Planet. Sci. Lett. 2006, $251,168-178$.

59. Evans, M.; Elmore, R.D. Fluid control of localized mineral domains in limestone pressure solution structures. J. Struct. Geol. 2006, 28, 284-301.

60. Wilkin, R.; Barnes, H. Formation processes of framboidal pyrite. Geochim. Cosmochim. Acta 1997, 61, 323-339.

61. Suk, D.; Peacor, D.; Van der Voo, R. Replacement of pyrite framboids by magnetite in limestones and implications for paleomagnetism. Nature 1990, 345, 611-613.

62. Suk, D.; Van der Voo, R.; Peacor, D. Origin of magnetite responsible for remagnetization of Early Paleozoic limestones of New York State. J. Geophys. Res. 1993, 98, 419-434.

63. Rowan, C.J.; Roberts, A.P. Magnetite dissolution, diachronous greigite formation, and secondary magnetizations from pyrite oxidation: Unraveling complex magnetizations in Neogene marine sediments from New Zealand. Earth Planet. Sci. Lett. 2006, 241, 119-137. 
64. Manning, E.B.; Elmore, R.D. Rock Magnetism and Identification of Remanence Components in the Marcellus Shale, Pennsylvania. In Remagnetization and Chemical Alteration of Sedimentary Rocks; Elmore, R.D., Muxworthy, A.R., Aldana, M.M., Mena, M., Eds.; Special Publications Volume 371; Geological Society London: London, UK, 2012; pp. 271-282.

65. Cairanne, G.; Aubourg, C.; Pozzi, J.-P.; Moreau, M.-G.; Decamps, T.; Marolleau, G. Laboratory chemical remanent magnetization in natural claystones: A record of two polarities. Geophys. J. Int. 2004, 159, 909-916.

66. Moreau, M.-G.; Ader, M.; Enkin, R. The remagnetization of clay-rich rocks in sedimentary basins: Low-temperature experimental formation of magnetic carriers in natural sample. Earth Planet. Sci. Lett. 2005, 230, 193-210.

67. Aubourg, C.; Pozzi, J.-P.; Janots, D.; Sahraoui, L. Imprinting chemical remanent magnetization in claystones at $95{ }^{\circ} \mathrm{C}$. Earth Planet. Sci. Lett. 2008, 272, 172-180.

68. Crouzet, C.; Ménard, G.; Rochette, P. High-precision three-dimensional paleothermometry derived from paleomagnetic data in Alpine metamorphic unit. Geology 1999, 27, 503-506.

69. Beyssac, O.; Simoes, M.; Avouac, J.-P.; Farley, K.A.; Chen, Y.G.; Chan, Y.C.; Goffé, B. Late Cenozoic metamorphic evolution and exhumation of Taiwan. Tectonics 2007, 26, doi:10.1029/2006TC002064.

70. Sweeney, J.J.; Burnham, A.K. Evaluation of a simple model of vitrinite reflectance based on chemical kinetics. AAPG Bull. 1990, 74, 1559-1570.

71. Barker, C.E.; Pawlewicz, M.J. Calculation of vitrinite reflectance from thermal histories and peak temperatures. In Reevaluation of Vitrinite Reflectance; Mukhopadhyay, P.K., Dow, W.G., Eds.; Series 570; American Chemical Society Symposium: Washington, DC, USA, 1994; pp. 216-229.

72. Bruner, K.R.; Smosna, R. A Comparative Study of the Mississippian Barnett Shale, Fort Worth Basin, and Devonian Marcellus Shale, Appalachian Basin. Available online: http:/www.netl.doe.gov/File\%20Library/Research/Oil-Gas/publications/brochures/DOE-NETL-2011 -1478-Marcellus-Barnett.pdf (accessed on 1 July 2014).

(C) 2014 by the authors; licensee MDPI, Basel, Switzerland. This article is an open access article distributed under the terms and conditions of the Creative Commons Attribution license (http://creativecommons.org/licenses/by/3.0/). 